\title{
IMPACT OF THE COVID-19 PANDEMIC ON SUBSTANCE USE AND DEPENDENCE: NEW RISKS AND CHALLENGES
}

\section{WPŁYW PANDEMII COVID-19 NA UŻYWANIE I UZALEŻNIENIE OD SUBSTANCJI PSYCHO- AKTYWNYCH: NOWE ZAGROŻENIA I WYZWANIA}

\author{
Sara Dehanov ${ }^{1} \mathbb{I D}$, Tiago Ferreira ${ }^{1}$, Manuela Fraga ${ }^{2}$ \\ ${ }^{1}$ Mental Health Department of Hospital Prof. Doutor Fernando Fonseca, Amadora, Portugal \\ ${ }^{2}$ Equipa de Tratamento de Coimbra, Divisão de Intervenção nos Comportamentos Aditivos e nas Dependências, Coimbra, Portugal \\ Alcohol Drug Addict 2020; 33 (4): 373-376 \\ DOI: https://doi.org/10.5114/ain.2020.104819
}

\section{Abstract}

The COVID-19 pandemic is a stress factor for the general population and has been associated with an increase in mental illnesses and psychoactive substance use disorders. Evidence indicates that there has been a switch in the pattern of use and choice of drugs, with increased use of licit substances such as alcohol. The population with substance use disorders is known to be particularly vulnerable, and this status may be worsened by the current pandemic, with increased risk of infection and severe illness. It is important that health services adapt to the new risks and challenges that this population faces.

Keywords: COVID-19 pandemic, Substance use disorders, Mental disorders, Addiction psychiatry.

\section{Streszczenie}

Pandemia COVID-19 jest czynnikiem stresogennym - powoduje nasilenie chorób psychicznych i zaburzeń związanych $\mathrm{z}$ używaniem substancji psychoaktywnych w populacji. Wzrost konsumpcji legalnych substancji psychoaktywnych, takich jak alkohol, pociągnął za sobą - co udowodniono - zmianę zarówno wzorów używania narkotyków, jak i wyboru ich rodzaju. Wiadomo, że osoby z zaburzeniami związanymi $\mathrm{z}$ używaniem substancji psychoaktywnych są pod wieloma względami grupą szczególnie zagrożoną. Pandemia COVID-19, ze zwiększonym ryzykiem zarażenia się i ciężkiego przebiegu choroby $\mathrm{w}$ tej grupie, może jeszcze to zagrożenie potęgować. Ważne jest zatem, by służba zdrowia, biorąc pod uwagę tę sytuację, dostosowała się do nowych zagrożeń i wyzwań.

Słowa kluczowe: pandemia COVID-19, zaburzenia związane $\mathrm{z}$ używaniem substancji psychoaktywnych, zaburzenia psychiczne, psychiatria uzależnień.

Correspondence to/Adres do korespondencji: Sara Duran Dehanov, Mental Health Department of Hospital Prof. Doutor Fernando Fonseca, EPE, IC-19, 2720-276, Amadora, Portugal, phone: +351 214348 270, fax: 214345566, e-mail: sara.dehanov@gmail.com

Authors' contribution/Wkład pracy autorów: Study design/Koncepcja badania: S. Dehanov; Data collection/Zebranie danych: S. Dehanov; Acceptance of final manuscript version/Akceptacja ostatecznej wersji pracy: S. Dehanov, T. Ferreira, M. Fraga; Literature search/Przygotowanie literatury: S. Dehanov, T. Ferreira, M. Fraga

No ghostwriting and guest authorship declared./Nie występują zjawiska ghostwriting i guest authorship.

Submitted/Otrzymano: 05.01.2021 • Accepted/Przyjęto do druku: 12.01.2021

(C) 2020 Institute of Psychiatry and Neurology. Production and hosting by Termedia sp. z o.o.

This is an open access article under the CC BY-NC-ND license (http://creativecommons.org/licenses/by-nc-nd/4.0/) 


\section{Dear Alcoholism and Drug Addiction Editors,}

The COVID-19 pandemic has led to the adoption of unprecedented measures to mitigate its evolution resulting in marked personal, social and economic impact. In this way, the pandemic can be viewed as a direct and indirect stress factor for the population. Its direct impact is determined by the generation of feelings of fear and uncertainty, which diminish the sense of predictability and control. The indirect impact stems from the mitigation measures and their socioeconomical consequences. All these factors taken together may lead to the emergence or aggravation of mental illness [1] as well as influence decision making and cause a change of priorities that may be crucial as regards substance use. Indeed, current evidence seems to indicate there has been an increase in psychoactive substance use since the pandemic began $[2,3]$ and changes in the pattern of consumption can be expected.

When considering the causes behind this growth in psychoactive substance use, some hypothesis may be of relevance. On the one hand, the fear of becoming ill or even dying as a consequence of the pandemic may lead to self-gratification behaviours including substance consumption, given its initial hedonic potential. In some cases, individuals may adopt an "anything goes" mode of functioning, trying new substances or intensifying the use of previously used ones, ignoring the negative consequences. On the other hand, a change in consumption levels may be observed as an adaptation mechanism to the negative emotions generated directly and indirectly by the pandemic. The latter may lead to comorbid substance use and mental illnesses like depression or anxiety, creating clinical conditions of higher complexity.

In addition to the reasons for initiating or increasing psychoactive substance use, it is also important to identify possible changes in chosen substance's use-patterns, which may be largely driven by availability and price [4]. As consequence of social distancing and confinement measures, a change will be expected regarding substances that can be consumed in a solitary manner and that have relaxing effects like opiates, benzodiazepines or alcohol [5]. Accordingly, data published by the European Monitoring Centre for Drugs and Drug Addiction (EMCDDA) have identified a switch from the consumption of illicit to licit substances in the period of confinement, reporting a higher alcohol and benzodiazepine intake both in terms of frequency and quantity [4]. It is also important to take into consideration that the mobility restrictions imposed by the pandemic may have caused changes to the drug markets. In this way, there appears to be an increased digitalisation of these markets, with more flexible distribution systems like home delivery [4], which can contribute to an increase in substance use. Additionally, there has been an increase in the role of the darknet, especially for cannabis products [4].

Regarding the population with psychoactive substance use disorders, several aspects must be taken into account in the current context. It is known that this population suffers from social stigma, which in the present situation may lead to it being seen as a non-priority in healthcare. It is also a population that is more vulnerable to the impact of containment measures [6] (mainly due to socioeconomic aspects), with potential greater difficulty in accessing that kind of care. These issues are worrying given the potential risks resulting from the modification of consumption patterns like abstinence syndromes or worse, accidental overdoses. Additionally, this is a population of greater physical vulnerability due to substance impact, as well as greater neglect of healthcare, and an increasing proportion of older people. All these aspects indicate a higher risk of severe symptoms, complications and death by COVID-19 in this population [7]. It is also significant to note that this is a group with an increased risk of exposure to the virus or viral spread mainly due to social vulnerability [8], which is another aggravating factor.

Health services need to adapt in order to provide care to these patients in the present pandemical context, mainly with respect to emergency situations like intoxications or abstinence syndromes. Opioid substitution therapy programmes should also be a priority to avoid relapses or misuse of these treatments. Health professionals should be aware of the new risks and challenges associated with this vulnerable population in order to improve intervention and avoid further marginalisation of the at-risk group. 


\section{Conflict of interest/Konflikt interesów}

None declared./Nie występuje.

Financial support/Finansowanie

None declared./Nie zadeklarowano.

\section{Ethics/Etyka}

The work described in this article has been carried out in accordance with the Code of Ethics of the World Medical Association (Declaration of Helsinki) on medical research involving human subjects, Uniform Requirements for manuscripts submitted to biomedical journals and the ethical principles defined in the Farmington Consensus of 1997.

Treści przedstawione w pracy są zgodne z zasadami Deklaracji Helsińskiej odnoszącymi się do badań $\mathrm{z}$ udziałem ludzi, ujednoliconymi wymaganiami dla czasopism biomedycznych oraz z zasadami etycznymi określonymi w Porozumieniu z Farmington w 1997 roku.

\section{References/Piśmiennictwo}

1. Xiong J, Lipsitz O, Nasri F, Lui LMW, Gill H, Phan L, et al. Impact of COVID-19 pandemic on mental health in the general population: a systematic review. $J$ Affect Disord 2020; 277: 55-64. DOI: 10.1016/j.jad.2020.08.001.

2. Sun Y, Li Y, Bao Y, Meng S, Sun Y, Schumman G, et al. Brief Report: Increased Addictive Internet and Substance Use Behavior During the COVID-19 Pandemic in China. Am $J$ Addict 2020; 29(4): 268-70. DOI: 10.1111/ajad.13066.

3. Dubey MJ, Ghosh R, Chatterjee S, Biswas P, Chatterjee S, Dubey S. COVID-19 and addiction. Diabetes Metab Syndr 2020; 14(5): 817-23. DOI: 10.1016/j.dsx.2020.06.008.

4. European Monitoring Centre for Drugs and Drug Addiction. Impact of COVID-19 on patterns of drug use and drug-related harms in Europe. EMCDDA Trendspotter briefing, Lisbon; 2020. DOI: 10.2810/830360.

5. Zaami S, Marinelli E, Varì MR. New Trends of Substance Abuse During COVID-19 Pandemic: An International Perspective. Front Psychiatry 2020; 11: 700. DOI: 10.3389/ fpsyt.2020.00700.

6. Volkow ND. Collision of the COVID-19 and Addiction Epidemics. Ann Intern Med 2020; 173(1): 61-2. DOI: $10.7326 / \mathrm{M} 20-1212$.

7. Wei Y, Shah R. Substance Use Disorder in the COVID-19 Pandemic: A Systematic Review of Vulnerabilities and Complications. Pharmaceuticals (Basel) 2020; 13(7): 155. DOI: $10.3390 / \mathrm{ph} 13070155$.

8. European Monitoring Centre for Drugs and Drug Addiction. The Implications of COVID-19 for People Who Use Drugs (PWUD) and Drug Service Providers. https://www. emcdda.europa.eu/publications/topic-overviews/covid-19-and-people-who-use-drugs_en (Accessed: 02.01.2020). 
